ISSN: 0514-7336

DOI: http://dx.doi.org/10.14201/zephyrus201780113130

\title{
TÁCITO, EL TEMPLO ROMANO DE LA C/ MORERÍA (CÓRDOBA) Y EL ORIGEN DEL CULTO PROVINCIAL EN BAETICA
}

\section{Tacitus, the Roman Temple of Morería Street (Córdoba) and the origin of the Provincial Cult in Baetica}

\author{
José Antonio Garriguet Mata \\ Dpto. de Historia del Arte, Arqueología y Música-UCO. Facultad de Filosofía y Letras. Plaza del Cardenal Salazar, 3. \\ 14071 Córdoba. Correo-e: aalgamaj@uco.es
}

Recepción: 17/09/2016; Revisión: 20/02/2017; Aceptación: 3/03/2017

Resumen: Desde finales del s. xix, el origen del culto imperial de carácter provincial en Hispania Ulterior Baetica -y en su capital, Colonia Patricia-Corduba - ha sido uno de los problemas historiográficos más discutidos por los especialistas de la Antigüedad hispana. Abordado tradicionalmente a partir del análisis de la documentación literaria y, sobre todo, epigráfica, en las últimas décadas el desarrollo de la investigación arqueológica en la ciudad de Córdoba - donde se han hallado restos de un recinto monumental, presidido por un templo marmóreo, que ha sido denominado forum novum - ha puesto de manifiesto la necesidad de contar también con los testimonios materiales para avanzar en su resolución. Tomando en consideración un controvertido texto de Tácito (Ann. Iv, 37), así como la información relativa al mencionado forum novum y su enorme templo, en este trabajo se plantea la posibilidad de que el culto provincial, o bien supralocal, se instaurase en la Bética, como en las otras dos provincias hispanas, poco después de la muerte de Augusto.

Palabras clave: Investigación histórica y arqueológica; adoración imperial; Hispania Ulterior; Colonia Patricia; época julioclaudia temprana.

AвsтRAct: Since the late nineteenth century, the origins of provincial imperial cult in Hispania Ulterior Baetica -and in its capital, Colonia Patricia-Corduba- has been one of the most discussed historiographical issues by the specialists of the Hispanic Antiquity. Traditionally addressed from the analysis of literary and, above all, epigraphic documentation, in recent decades the development of archaeological research in the city of Córdoba (where the remains of a monumental area dominated by a large marble temple, known as forum novum, have been found) has highlighted the need to also consider the material evidence for advancing towards its resolution. Taking into account a controversial text of Tacitus (Ann. Iv, 37) as well as the information related to the mentioned forum novum and its colossal temple, this contribution raises the possibility that the provincial, or if preferred supralocal, cult was established in Baetica, as in the other two Hispanic provinces, shortly after Augustus' death.

Key words: Historical and archaeological research; Imperial worship; Hispania Ulterior; Colonia Patricia; Early JulioClaudian era. 


\section{Introducción}

"Per idem tempus Hispania ulterior, missis ad senatum legatis, oravit ut exemplo Asiae delabrum Tiberio matrique eius extrueret”. Este pasaje de Tácito (Ann. IV, 37), o más bien la negativa de Tiberio a satisfacer el piadoso deseo de los béticos, ha sido el principal argumento esgrimido durante más de un siglo por numerosos historiadores para rechazar la implantación del culto provincial en Baetica antes de Vespasiano (Krascheninnikoff, 1894: 180 y ss.; Étienne, 1958: 126 y s.; Deininger, 1965: 31 y ss.; Fishwick, 1987: 219 y ss.; Pailler, 1989; González, 2007: 175 y s.). Ello se ha cimentado también en la ausencia de monedas de Colonia Patricia, capital de Baetica, con imágenes de monumentos de culto imperial, la cronología de los primeros flamines provinciales ${ }^{1}$ y las concomitancias observadas entre los honores recibidos por dichos sacerdotes y los recogidos en la Lex de flamonio provinciae Narbonensis (CIL XII, 6038) ${ }^{2}$. Sin embargo, también ha habido voces discrepantes. Así, Fiske (1900: 137 y s.), Kornemann (1901: 122 y ss.) o Abaecherli (1935: 167 y s.) plantearon la existencia del culto bético en época julioclaudia; idea retomada recientemente, primero con cautela (Le Roux, 1994: 399; Castillo, 1998: 438) y después, tras los avances en el conocimiento arqueológico de la Córdoba

1 In memoriam D. Fishwick. Actualmente, cerrada ya la polémica sobre el flamen augustal de Castulo (Fishwick, 1987: 221 y ss.) -el primero de su ciudad, no de la provincia, en ejercer el flaminado provincial (Panzram, 2003: 122)-, el sacerdote bético más antiguo es C. Sempronius Speratus (CIL II $\left.{ }^{2} / 7,799\right)$, que ocupó su cargo en 98-99 d. C. (Delgado, 1998: 41 y ss.; Castillo, 1998, 1999). No obstante, la revisión realizada por Goffaux (2013) del cursus honorum de un flamen provincial de Igabrum obliga a no descartar la existencia del flaminado preflavio en la Bética.

2 La evidente relación de varias inscripciones de sacerdotes béticos (CIL II ${ }^{2} / / 7,291,293,295$ y 799) con la Lex Narbonensis, probablemente obra de Vespasiano, ha llevado a pensar a Fishwick (1987: 240 y ss.; 2012) en una ley similar para Baetica, promulgada también por aquel. romana, de forma más firme (Garriguet, 2002: 160 y ss.; Ventura, 2007b) ${ }^{3}$.

En las páginas siguientes trato de nuevo el tema, en absoluto cerrado, del origen del culto provincial en Baetica (Fig. 1), ofreciendo propuestas e hipótesis alternativas a las comúnmente aceptadas y abriendo nuevos interrogantes de cara a ulteriores estudios. Para ello me centro en los hallazgos acaecidos hace dos décadas en la c/ Morería de Córdoba, correspondientes a un gran espacio público presidido por un templo colosal. Con ello pretendo reivindicar el papel que la arqueología, junto a las fuentes literarias, epigráficas o numismáticas, debe jugar en la resolución de problemas históricos.

\section{Roma, Augusto y los inicios del culto provincial en Occidente}

El establecimiento del culto provincial, o regional, en el occidente del Imperio se vincula a la erección,

3 Investigadores que hace no mucho defendían la datación flavia del culto provincial bético parecen aceptar ya la posible existencia de este con los julioclaudios (Panzram, 2010: 378; Fishwick, 2012: 156). 
poco antes del cambio de Era y por iniciativa del poder imperial, de altares dedicados a Roma y a Augusto en territorios limítrofes, apenas romanizados y de incierto control militar (Fishwick, 2014a). Una de esas arae, el "Altar de las Tres Galias", fue levantada por Druso maior c. 12 a. C. junto a la confluencia de los ríos Ródano y Saona, cerca de Lugdunum. En torno a ella surgió un santuario federal para el culto al emperador vivo donde anualmente se reunían representantes de Aquitania, Belgica y Gallia Lugdunensis (Hänlein-Schäfer, 1985: 246 y ss.; Fishwick, 1987: 97 y ss.; 2002: 9 y ss.). Otro altar territorial, el Ara Ubiorum, fue dedicado c. 12-9 a. C. junto a la población de los ubios que después dio origen a Colonia. Allí también fue Druso el Mayor - ¿o Tiberio?- quien instauró el culto imperial entre gentes recientemente sometidas (Hänlein-Schäfer, 1985: 252 y ss.; Fishwick, 1987: 137 y ss.; 2002: 20). En el Noroeste de la Península Ibérica, quizá cerca de Finisterre, se emplazaron las Arae Sestianae, tres altares erigidos c. 22-19 a. C. por L. Sestius Quirinalis, gobernador de Hispania Ulterior, que habrían actuado como centro del culto al emperador y foco de romanización entre pueblos de Callaecia y Asturia (Fishwick, 1987: 141 y ss.; 2002: 6 y ss.), además de como marcadores del límite occidental del mundo conocido (Grüner, 2005).

En fechas más o menos coetáneas dio comienzo asimismo - de forma "espontánea" y directa o a través de su genius o numen- el culto a Augusto en ciudades de Italia y del Occidente latino ${ }^{4}$. Además de en teatros (Gros, 1990), este culto cívico se celebró alrededor de aras -como las de Tarraco y Narbo

4 Para el inicio del culto local a Augusto vivo en Occidente, $c f$. Fishwick (1987: 73 y ss.) y Zanker (1992: 343 y ss.). Respecto a la Península Ibérica, además de la obra de Étienne (1958) resultan de interés las contribuciones al tema de Lozano y Alvar (2009) y Alarcón (2013), que rechazan la propuesta de aquel sobre el supuesto papel de la devotio ibérica en el surgimiento del culto hispano a Augusto.

5 No se conocen restos del altar de Tarraco mencionado por Quintiliano (Instit. Orat. 6, 3, 77) y representado en monedas tiberianas de la ciudad ( $R P C$ i n. ${ }^{\text {os }} 218,221,225$ y 231). Según algunos autores (Fishwick, 2014a: 57-59; Ruiz de Arbulo, 2009: 177 y s.), se ubicó en el foro colonial, pero otros (Mar et al., 2012: 341 y ss.) lo sitúan en la acrópolis
(Fishwick, 1987: 146, 171 y ss., 245) o Arelate (Gros, 1987: 346 y ss.)- y templos forenses -Pula, Vienna (Hänlein-Schäfer, 1985: 149 y ss., 244 y ss.; Pensabene, 2004: 177), Augusta Emerita (Álvarez-Nogales, 2003; Pensabene, 2004: 184 y s.) o Barcino (Pensabene, 2004: 184 y s.; Rodà, 2007: 748 y s.)dedicados a Augusto solo o junto a Roma ${ }^{7}$.

En suma, el culto provincial previo a época tiberiana se desarrolló en Occidente alrededor de altares regionales erigidos en áreas fronterizas y de reciente incorporación al Imperio; no en torno a templos o aras urbanos de territorios integrados, por lo general, desde hacía tiempo en la órbita de Roma, donde se generó un culto cívico.

\section{Templos provinciales para Divus Augustus}

En septiembre del $14 \mathrm{~d}$. C., casi un mes después de su muerte, el Senado romano divinizó a Augusto $^{8}$, que se convirtió así en Divus Augustus ${ }^{9}$. Para atender su culto se creó un sacerdocio específico - flamen Augustalis $\_{ }^{10}$, cargo ocupado en primer lugar por Germánico (Lyasse, 2007: 316 y ss.). Livia, la viuda del Princeps, fue designada sacerdotisa del nuevo

tarraconense y dudan entre su vinculación al culto local o provincial.

6 Se trata del llamado "Templo de Diana", cuya dedicación a Augusto y Roma se considera posible (Álvarez-Nogales, 2003: 286 y ss.; Saquete y Álvarez, 2007: 399) o indudable (Gros, 2009: 333). Mateos (2006b: 347), en cambio, cuestiona su conexión con el culto imperial, al menos en sus inicios.

7 Además de esas construcciones, el citado culto necesitó lógicamente sacerdotes y otros cargos dependientes de las curias; $c f$. para Hispania, Étienne (1958: 197 y ss.), Delgado (1998; 2011) y González Herrero (2009: 445 y ss.).

8 Tac., Ann. I, 10; Cass. Dio, Lvi, 46, 3.

9 El segundo de los divi de Roma tras Divus Iulius. Para el culto a éste, instaurado en 42 a. C., véanse el trabajo clásico de Weinstock (1971) y los de Hänlein-Schäfer (1985: 99 y ss., 255 ss.), Fishwick (1987: 56 y ss.) o Gradel (2002: 54 y ss.), así como la reciente monografía de Koortbojian (2013).

10 Augusto ya dispuso en vida de un flamen Augustalis en Pisa. Por otro lado, para el culto de Divus Augustus se crearon también los sodales Augustales (Lyasse, 2007: 314 y ss.). 
divus $^{11}$ y junto con el nuevo emperador, su hijo Tiberio, asumió la construcción de un templo para aquel en Roma ${ }^{12}$, concluido por Calígula ${ }^{13}$. Numerosas ciudades de Italia y de las provincias occidentales crearon de inmediato sacerdocios y otros cargos menores, subordinados al ordo decurionum, para rendir culto a Divus Augustus. En dichas comunidades se consolidó, además, la práctica de dedicar templos y/o aras forenses para el culto imperial (cf. supra). Leptis Magna ${ }^{14}$ (Hänlein-Schäfer, 1985: 226 y ss.; Livadiotti y Rocco, 2005: 230), Ebora (Hauschild, 1991; Pensabene, 2004: 185) y, tal vez, Ostia ${ }^{15}$ (Hänlein-Schäfer, 1985: 130; Gros, 2000: 316) construyeron en sus foros templos dedicados a Augusto. Arelate (Gros, 1987: 357 y ss.; Pensabene, 2004: 179) levantó un recinto monumental adosado a su plaza cívica. Y en Augusta Emerita, Ilici e Italica es posible que se instalasen altares, aunque sólo contamos con testimonios numismáticos de época tiberiana para plantear, no sin dudas, su existencia (Chaves et al., 2000) ${ }^{16}$.

A diferencia de lo acontecido en el nivel local, la divinización de Augusto conllevó un cambio sustancial para el culto provincial en Occidente, como evidencia la embajada hispana enviada a Roma en 15 d. C. a fin de solicitar permiso a Tiberio para levantar un templo a Augusto en Tarraco. Conseguida la autorización, este hecho, que "dio ejemplo a todas las provincias" ${ }^{17}$, habría supuesto el inicio del citado culto en Hispania Citerior (Étienne, 1958: 406; Fishwick, 1987: 150 y ss.).

11 Dio. Cass., LVI, 41, 1-2.

12 Dio Cass., LVI, 46, 3. Mientras se erigía el citado templo, una estatua de oro de Divus Augustus fue incluida en el de Mars Ultor (Suet., Cal. 21.1).

13 Dio Cass., LIX, 7, 1; Suet., Cal. 21.

14 Bullo (2002: 175-176) considera que las obras de dicho edificio se iniciaron en época augústea tardía.

15 Calandra (2000: 442 y ss.) sitúa la erección del templo ostiense en el periodo tardoaugústeo. Pensabene (2004: 177) lo fecha entre 5-20 d. C., dejando abierto el problema.

16 Las monedas emeritenses muestran un ara Providentiae ( $R P C$ I n. ${ }^{\text {os }} 28,34-36$ y 45-46), al que tal vez perteneciesen los relieves de Pancaliente (Nogales, 2000). En las de Ilici figuran un altar y la leyenda Salus Augusta (RPC I n. ${ }^{\text {os }}$ 196-197) y en las de Italica, un ara dedicada a la Providentia Augusti (RPC I n. ${ }^{\text {os }}$ 64-65).

17 Tac. Ann. I, 78.

\subsection{Templum ut in colonia Tarraconensis...}

La existencia del templo de Tarraco se basa en la famosa cita de Tácito $^{18}$, en otras menciones literarias ${ }^{19}$ y epigráficas del edificio (Peña et al., 2015) y en las monedas acuñadas en época tiberiana por la colonia con la imagen de un templo octástilo y la leyenda $A e-$ ternitatis Augustae (RPC I n. ${ }^{\text {os }} 219,222,224$ y 226). No obstante, el conocimiento arqueológico del templo tarraconense es muy limitado, lo que ha suscitado largas controversias sobre su ubicación, apariencia o relevancia para el desarrollo del culto provincial en la Citerior. Últimamente, el estudio de elementos arquitectónicos dispersos (Pensabene y Mar, 2004, 2010) y las excavaciones acometidas en la parte alta de la ciudad (Macias et al., 2007, 2014) han empezado a arrojar luz acerca de tales cuestiones. Así, el hallazgo bajo la nave central de la catedral medieval de una plataforma de opus camenticium parece haber zanjado la discusión sobre la zona de Tarragona -la parte baja o la acrópolis-donde se situó el templo de Augusto, ya que dicha estructura pudo pertenecer a la cimentación de aquel. Sin embargo, la arqueología no ha aclarado aún la fecha de su construcción, fijada en época tiberiana gracias al texto de Tácito y a las monedas aludidas. Además, las dimensiones de la plataforma resultan problemáticas, pues permiten reconstruir un templo octástilo y períptero similar al de Mars Ultor en Roma (Macías et al., 2014); pero su tamaño no concuerda con el calculado a partir del análisis de piezas arquitectónicas atribuidas al edificio (Pensabene y Mar, 2004: 78 y ss.; 2010: 255 y ss.). En cualquier caso, el templo se integró después en el recinto de culto $^{20}$ que presidió el gran complejo arquitectónico

18 Interpretada de forma muy distinta por Castillo (2015), para quien Tácito se refiere a una legación hispana que solicitó a Augusto, no a Tiberio, permiso para construir un templo en Tarraco.

19 Vit. Hadr. XII, 3-5; Sev. III, 3.

20 Donde se imitó, parcialmente, la decoración del Forum Augustum (Goldbeck, 2015). En el pórtico del fondo, tras el templo, pero en su mismo eje y con idénticas dimensiones, se erigió en época flavia una sala interpretada como curia provincial (Mar et al., 2013); a la cual pertenecería un friso decorado con bucráneos, guirnaldas e instrumentos sacerdotales (Pensabene y Mar, 2004: 80 y ss.; 2010: 255 y ss.). 
en terrazas de la provincia, levantado con mármol de Luni en la acrópolis de Tarraco durante la etapa flavia (Pensabene y Mar, 2010; Mar et al., 2015: 83 y ss.) ${ }^{21}$.

Al margen de su emplazamiento o tipología arquitectónica, lo más interesante aquí es el papel que el templo de Augusto jugó en la implantación del culto provincial en Hispania Citerior. Según Fishwick (1987: 154; 2002: 43 y ss.), la erección de un edificio de culto local no habría necesitado un permiso imperial, mientras que la autorización del emperador era imprescindible para un templo provincial. A favor de un carácter no local apuntan, asimismo, la complejidad del proyecto o su magnitud y enorme coste (Domingo, 2015). Pero el hecho de que no se conozcan aún flamines provinciales anteriores a los flavios ${ }^{22}$ ha llevado a dudar del origen de los fondos empleados en la construcción del templo y de cuándo y cómo se desarrolló realmente el culto provincial en la Citerior (Ruiz de Arbulo, 2014: 44; Mar et al., 2012: 348, $360)$. Incluso se ha sostenido que aquel pudo ser una iniciativa de las élites locales para el culto colonial, aunque después se incorporase al complejo de la provincia (Macías et al., 2007: 782; Gros, 2009: 332). ¿Qué interpretación cabría hacer, pues, del templo de Tarraco? ¿Fue desde el principio un edificio para el culto provincial? ¿Cómo pudo celebrarse este en época julioclaudia sin flamines?

\subsection{Tras los pasos de Tarraco: el templo provincial de Augusta Emerita}

Ningún escritor antiguo alude a la existencia en Augusta Emerita de un templo dedicado a Augusto ${ }^{23}$.

21 Este vasto complejo no sólo se habría construido para acoger los ritos y fiestas celebrados en honor de los divi y Augusti por el concilium provinciae, sino también, sobre todo, para albergar edificios de la administración provincial (Ruiz de Arbulo, 2007; Mar et al., 2013).

22 Fishwick (2002: 52 y s.) atribuye esta situación a la falta de costumbre de homenajear a los flamines provinciales en época julioclaudia y/o la utilización de un tipo de soporte, la placa, más frágil que los pedestales de estatua dedicados a aquellos a partir de la dinastía flavia.

23 Ello no sorprende si se tienen en cuenta las palabras de Tácito sobre el ejemplo que el templo de Tarraco supuso
Sin embargo, monedas acuñadas en la capital lusitana en época tiberiana muestran un edificio tetrástilo con la leyenda Aeternitati Augustae (RPC I n. ${ }^{\text {s }} 29$ y 47-48). Ello ha conducido tradicionalmente a afirmar que la instauración del culto provincial en $L u$ sitania aconteció, como en Hispania Citerior, bajo Tiberio (Étienne, 1958: 414; Fishwick, 1987: 156 y ss.); circunstancia corroborada por la epigrafía, pues al menos uno de los flamines lusitanos actualmente conocidos lo fue en época de aquel y otros desempeñaron su cargo en la de Claudio (Delgado, 1999, 2011; González Herrero, 2015).

Por otro lado, trabajos arqueológicos realizados en Mérida en las últimas décadas han descubierto un espacio monumental distinto al foro colonial y de cronología posterior ${ }^{24}$ que ocupó una superficie de cuatro insulae, elevándose respecto al entorno (Mateos, 2006b: 318 y ss.). Este nuevo recinto, rodeado de pórticos al menos por tres de sus lados, tuvo como acceso principal el llamado "Arco de Trajano" y acogió en su centro un gran templo de mármol blanco, hexástilo -no tetrástilo como el de las monedas- y de orden corintio, cuyos restos se localizaron en la c/ Holguín (Mateos, 2006a; 2007: 379 y ss.). Su planta sería similar a la de la Aedes Concordiae de Roma, restaurada por Tiberio en 9-10 d. C. con su característica cella "barlonga".

La epigrafía hallada en las inmediaciones de este magno espacio público, fundamentalmente inscripciones imperiales de los ss. I-IV d. C. (Saquete, 2005; Stylow, 2006), ha llevado a considerarlo un recinto de culto provincial (Álvarez y Nogales, 2003: 297 y ss.; Mateos, 2006a: 271 y ss.; 2006b: $337)^{25}$. Como ha argumentado Saquete (2005), en su construcción probablemente intervino L. Fulcinius Trio, gobernador de Lusitania entre 21? y 31 d. C., quien tal vez contase con la ayuda de $L$. Cornelius Bocchus (Mateos et al., 2011), prafectus

para las demás provincias (Fishwick, 2002: 41; Saquete, 2005: 304 y ss.).

24 Como demuestra el hecho de que parte del cardo máximo y varias viviendas de la colonia augústea fueron amortizados para su construcción.

25 Según Gros (2009: 333), el templo de la c/ Holguín fue “...sans doute voué au culte provincial des divi...”. 
fabrum hasta en cinco ocasiones y posteriormente flamen de la provincia ${ }^{26}$. La presumible relación de Fulcinius Trio con el templo de la c/ Holguín situaría la erección de éste en los años 20 del s. I d. C., cronología coincidente con la que proporcionan el análisis de su ornamentación arquitectónica ${ }^{27}$ y los contextos cerámicos documentados en el entorno del templo (Mateos, 2006a: 270). Así pues, por su datación y monumentalidad este debió de estar consagrado, como el de Tarraco, a Divus Augustus.

\section{El templo de la c/ Morería y el forum novum}

El análisis exhaustivo de piezas arquitectónicas y escultóricas halladas en la calle Morería y sus alrededores permitió a Márquez (1998: 176 y ss.) proponer la existencia en Córdoba de un gran templo y su plaza justo al sur del foro colonial, a la manera de un forum adiectum. Posteriormente, una excavación realizada en dicha calle confirmó la citada tesis, descubriendo restos del podium de un templo, el asiento de las losas del espacio que lo rodeaba y diversos elementos marmóreos (García y Carrasco, 2004: 159 y ss.) (Fig. 2). El hallazgo del forum adiectum, o novum, se incorporó de inmediato a la bibliografía arqueológica sobre Colonia Patricia (León, 1999; Fishwick, 2000; Garriguet, 2002: 119 y ss.), a la par que se analizaban su modelo y elementos compositivos (Márquez, 2004: 109 y ss.; Márquez y Ventura, 2005: 448 y ss.). Pero ha sido últimamente cuando más se ha avanzado en su conocimiento e interpretación (Ventura, 2007b; Peña, Ventura y Portillo, 2011) $)^{28}$.

26 Una inscripción descubierta en el foro colonial emeritense vincula a estos dos personajes, aunque su estado fragmentario ha generado tres lecturas distintas (Mateos et al., 2011; Saquete, 2011; González Herrero, 2015: 18 y ss.).

${ }^{27}$ Pensabene (2004: 184) fecha el templo entre $10 \mathrm{y}$ $30 \mathrm{~d}$. C.

28 Cf. también Portillo, A.: El templo de la calle Morería en el Forum Novum de Colonia Patricia. Análisis arquitectónico y funcional. Tesis doctoral presentada en 2016 en la Univ. de Córdoba.

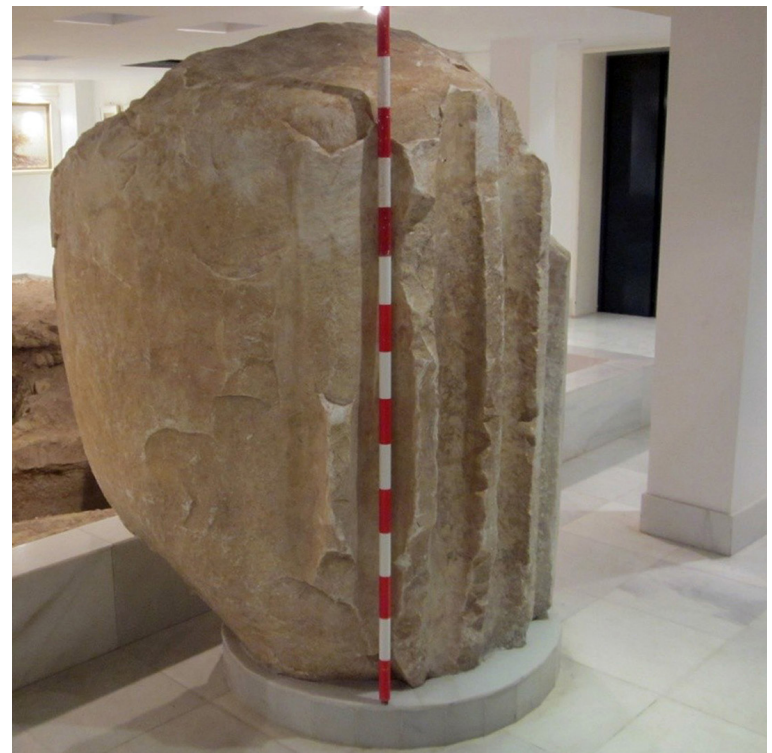

Fig. 2. Fragmento de fuste colosal perteneciente al templo de la cl Morería de Córdoba (fotog. Portillo, op. cit. n. 28).

\subsection{Ubicación y dimensiones}

Los datos obtenidos en la excavación de la c/ Morería y en intervenciones próximas evidencian que el forum novum ocupó cuatro manzanas de la ciudad, duplicando así la superficie del foro colonial (Fig. 3). Como en Mérida, su construcción conllevó el arrasamiento de viviendas preexistentes ${ }^{29}$. Asimismo, amortizó parte del decumano máximo occidental, que actuó como eje transversal de todo el conjunto ${ }^{30}$. El templo de mármol que lo presidió -ante el cual se erigió un gran altar (Márquez, 2009: 113 y ss.; Márquez y Ventura, 2005: 451 y ss.) - se situó en posición centrada y orientado hacia el Oeste (Márquez, 2004: 117) ${ }^{31}$ (Fig. 4). La decoración arquitectónica evidencia el gigantismo del edificio, equiparado en tamaño a los Aurea Templa de Roma y ligeramente inferior al de Mars Ultor

29 Restos de una domus construida hacia el último tercio del s. I a. C. y destruida en el primer cuarto del s. I d. C. se localizaron en el solar de Morería (García y Carrasco, 2004: 158 y ss.).

30 Portillo, op. cit. n. 28: 30 y ss., 53 y ss.

31 Portillo, op. cit. n. 28: 52 y ss. 


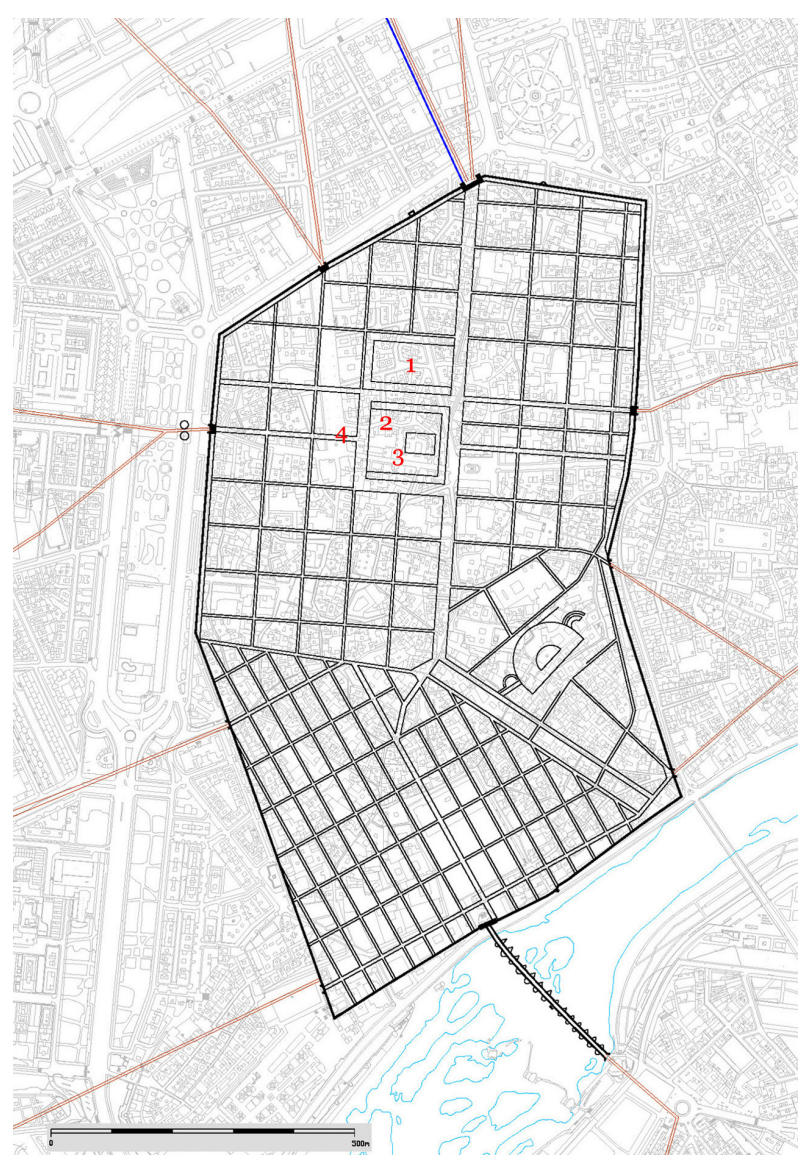

Fig. 3. Planimetría general de Córdoba en época tiberiana: 1) foro colonial; 2) forum novum; 3) templo de la $c /$ Morería; 4) decumano máximo occidental (plano de J. M. a Tamajón).

(Márquez, 2004: 113 y s.), su modelo. El templo, podium incluido, alcanzó una altura de casi $30 \mathrm{~m}$. Sus 29,6 m de anchura -unos 100 pies- permiten considerarlo octástilo y de ritmo picnóstilo (Ventura, 2007b: 223 y s.) $)^{32}$ (Fig. 5).

\subsection{Materiales, ornamentación y talleres}

La decoración arquitectónica del forum novum y su templo fue realizada mayoritariamente en mármol de Luni (Márquez, 2004: 114 y ss.) ${ }^{33}$, aunque también se usaron otros mármoles blancos -tanto importados como locales (Márquez, 2004: 115)- y

32 Portillo, op. cit. n. 28: 54 y ss.

33 Ibidem: 79 y ss. polícromos, estos principalmente para solerías interiores de opus sectile (Gutiérrez, 2007: 100 y ss.). Sólo el templo necesitó unos $1.400 \mathrm{~m}^{3}$ de mármol lunense, mientras que su coste total pudo ascender a unos 2,7 millones de sestercios (Ventura, 2007b: 224 y n. 9). Es decir, el forum novum fue una empresa prestigiosa, acorde con la ideología oficial del momento y extremadamente cara, tanto por el empleo masivo de mármol foráneo como por la contratación de mano de obra importada y muy cualificada. De ahí que se haya planteado una posible intervención imperial para asumir, en parte, el elevado importe del proyecto; tal vez facilitando el modelo a imitar y el suministro del material marmóreo. No obstante, la financiación debió de recaer, sobre todo, en las élites patricienses (Márquez, 2004: 116; 2009: 118 y ss.).

El estilo de los elementos arquitectónicos del templo de la c/ Morería remite al del Mars Ultor

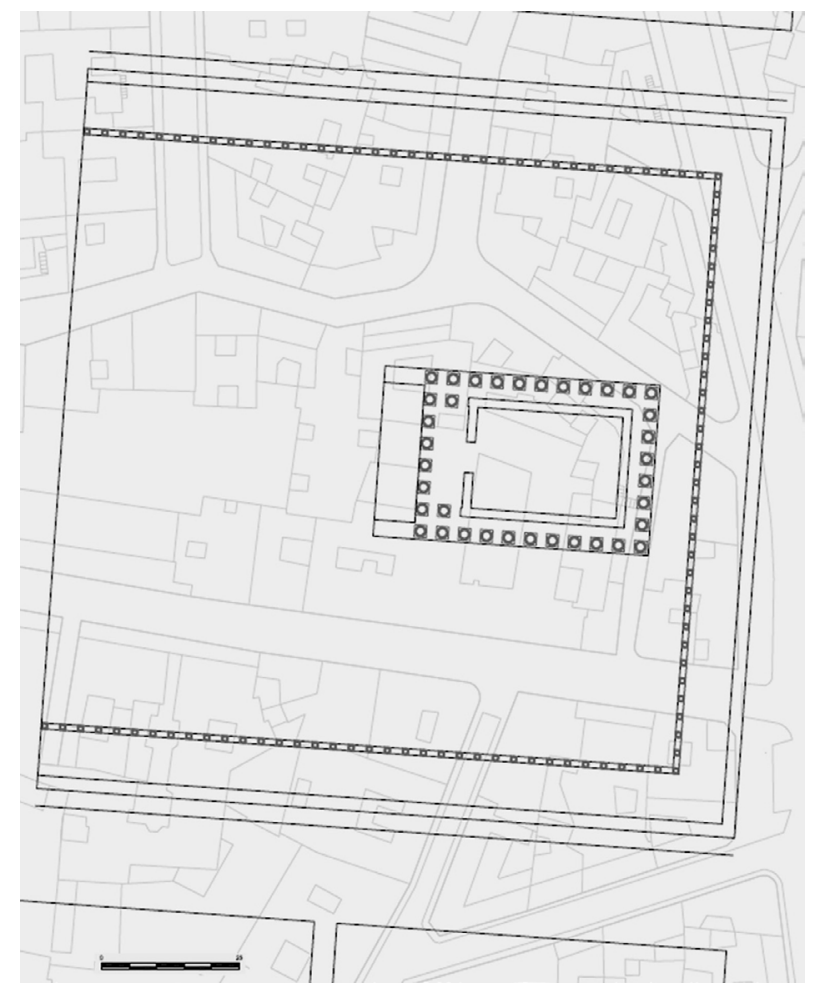

FIg. 4. Delimitación del forum novum de Colonia Patricia y ubicación en el mismo del templo de la cl Morería (según Portillo, op. cit. n. 28; plano de J. M.a Tamajón). 
(Márquez, 2004: 110 y ss.). La ornamentación escultórica atribuida al forum novum -como una colosal estatua thoracata o un pie con mulleus (López y Garriguet, 2000: 51 y ss.) ${ }^{34}$ indicaría que en él se imitó el programa ornamental del Forum Augustum de Roma (Goldbeck, 2015: 81 y ss.). Las semejanzas entre las piezas arquitectónicas de uno y otro son tales que Márquez (2002: 170 y ss.; 2004: 113 y s.) defiende la intervención en Córdoba de un buen taller romano o centroitálico, quizás el mismo que trabajó en el Foro de Augusto.

\subsection{Cronología, dedicación e interpretación}

El complejo de la c/ Morería ha sido datado en época tardoaugústea o tiberiana a raíz de su decoración arquitectónica (Márquez, 2002: 172; 2009: 112). Por su parte, las cerámicas asociadas al arrasamiento de la domus localizada bajo el templo sitúan su construcción en el primer cuarto del s. I d. C. (García y Carrasco, 2004: 159); y el módulo de las losetas de opus sectile conduciría a época augústea (Gutiérrez, 2007: 100 y ss.). Resulta muy difícil precisar más cuándo se materializó tan magna empresa, que pudo dilatarse en el tiempo -especialmente en lo que atañe al programa ornamental (Peña, 2009: 575; Goldbeck, 2015: 83)debido a su enorme coste. Ahora bien, para avanzar en la interpretación del forum novum y su templo debe atenderse al momento inicial de las obras, que, según las actuales evidencias, tuvo lugar en alguna de las etapas siguientes:

\subsubsection{Primera posibilidad: época tardoaugústea}

El estrecho parentesco que la decoración arquitectónica del forum novum y su templo mantiene con programas ornamentales de la Roma augústea y la posible intervención en el foro patriciense de maestros que trabajaron en el Forum Augustum abogarían a favor de una datación del complejo

34 Cf. también Portillo, op. cit. n. 28: 83 y ss.

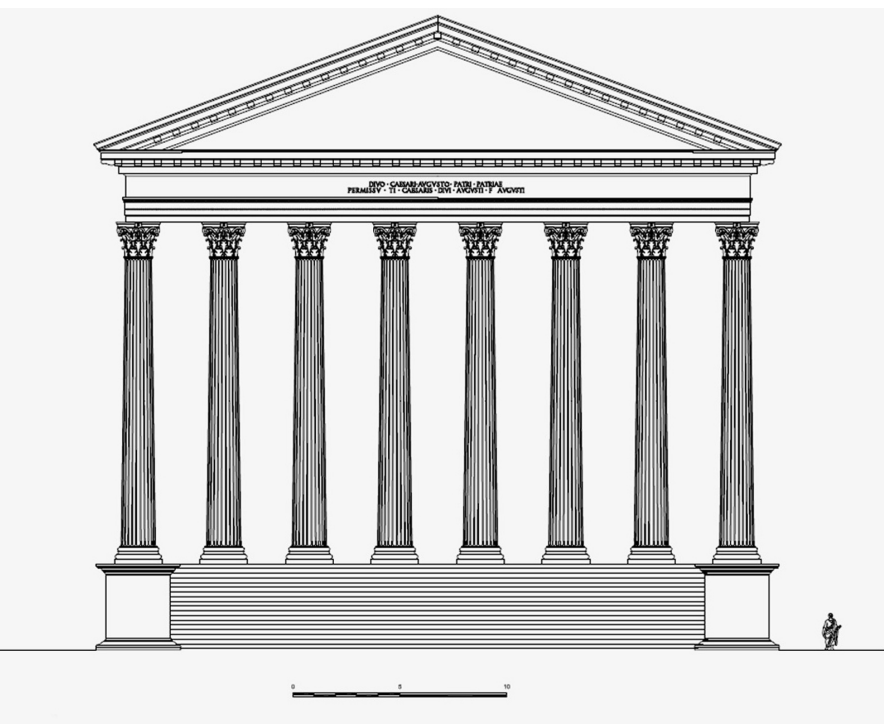

FIG. 5. Propuesta de restitución de la fachada del templo de la c/ Morería (Portillo, op. cit. n. 28).

cordobés próxima a las fechas en las que aquel se concluyó $^{35}$. Pero si el templo hubiese comenzado a construirse en época tardoaugústea no habría podido ser entonces un edificio "provincial"; pues el culto provincial anterior a Tiberio quedó circunscrito en Occidente a áreas limítrofes y apenas romanizadas; y tampoco se habría dedicado, al menos en origen, a Divus Augustus, ya que por esos años el Princeps, aún vivo, no había sido divinizado.

En consecuencia, una datación del inicio de las obras a finales del principado de Augusto implicaría que el forum novum fue proyectado y financiado por las élites patricienses, contando quizá con el apoyo del emperador ${ }^{36}$. Su construcción junto al viejo foro de la colonia, aunque en posición más elevada ${ }^{37}, \mathrm{y}$ prolongando hacia el s sus límites oriental y occidental, podría indicar la vinculación de este espacio con los asuntos locales (Márquez, 2004: 116 y ss.; 2009: 112 y 118). Por otro lado, una cronología

35 Sobre el Forum Augustum, su configuración y ornamentación, y las imitaciones que suscitó, $c f$. Goldbeck (2015).

36 Las relaciones de los emperadores con las comunidades locales, a las que aquellos ayudaron a menudo en proyectos constructivos, han sido objeto de un interesante y reciente estudio de Edmondson (2015).

37 Portillo, op. cit. n. 28: 34. 
tardoaugústea conllevaría que el templo se consagrase a una divinidad del panteón romano o a Augusto vivo (a través de alguna virtud o abstracción imperial, o de forma directa y junto a Roma). No obstante, es posible que la dedicación pensada inicialmente para el templo en su constitutio se modificase tras morir Augusto, estuvieran las obras concluidas o no. Nuevas dedicaciones de edificios religiosos en pie, o casi, no faltan en el mundo romano (Fishwick, 1987: 203 y ss.). Más difícil resultaría, en principio, que un espacio creado por las élites coloniales para acoger, entre otras actividades, la liturgia del culto local hubiese pasado poco después a manos del procónsul de la provincia y/o al servicio del concilium de esta.

Ahora bien, ¿qué habría llevado a Colonia Patricia a realizar en época tardoaugústea tan descomunal ampliación de su centro cívico? La ciudad creció notablemente en superficie y población bajo Augusto, pero jjustificarían las necesidades jurídico-administrativas de la colonia la construcción, aún en vida de este, de tan costoso y monumental complejo? El foro colonial fue renovado unas décadas antes (Ventura, 2007a: 97) y, sin embargo, mantuvo límites similares a los de la época republicana (Márquez, 2009: 108 y ss.; Márquez y Ventura, 2005: 430 y ss.). Por otro lado, ¿disponía dicho foro a principios del s. I d. C. de un templo de culto imperial como los que en fechas similares presidieron las plazas de numerosas ciudades o carecía del mismo? Si en el foro colonial hubiera existido un templo augústeo dedicado al Princeps no parece factible que las élites locales le erigiesen una segunda aedes aún en vida en un recinto anexo. Distinto sería que en el foro augústeo de Córdoba no se hubiese alzado un templo, sino un altar, para celebrar el culto cívico a Augusto; o que en aquel existiera un santuario dedicado a Divus Iulius ${ }^{38}$.

38 El culto a Divus Iulius fue acogido en ciudades de Italia y del Imperio que debían su estatuto municipal o colonial a César (Weinstock, 1971: 401 y ss.). Para Hispania, se ha planteado que en Tarraco, colonia cesariana, fuese venerado en un templo construido ex profeso, o bien en el Capitolio (Ruiz de Arbulo, 2014: 42). También se ha sugerido que el templo representado en monedas augústeas de Gades, municipio con César, fue consagrado a Divus Iulius (Chaves et al., 1999: 93 y s.). Dado que Corduba recibió al parecer su

\subsubsection{Segunda posibilidad: época tiberiana temprana}

La decoración arquitectónica y los datos arqueológicos obtenidos en la c/ Morería permiten plantear una opción cronológica muy próxima a la anterior, pero con significado harto diferente: que el forum novum se erigiese a comienzos del principado de Tiberio. En este caso, la dedicación del templo a Divus Augustus apenas presentaría dudas. Pero ahora habría que determinar si el mismo fue colonial o provincial. Los argumentos topográficos antes enunciados - la inserción del nuevo espacio en el centro de la urbe y su anexión al foro cívico- podrían aducirse de nuevo para postular la vinculación del forum novum a la colonia y al culto local. Sin embargo, la situación del culto imperial no era ya la del periodo tardoaugusteo. Augusto había sido divinizado y la difusión de su culto por las provincias era vital para su sucesor. El deseo - ¿espontáneo, estimulado por el gobernador provincial?-39 de los hispanos de erigirle un templo en Tarraco contribuyó a este objetivo, originando la primera transformación del culto provincial en Occidente. En ella habrían jugado un rol crucial recintos monumentales edificados en las capitales provinciales y presididos por templos consagrados a Divus Augustus. Por tanto, habría que preguntarse si en la Córdoba de época tiberiana temprana se erigió un templo para aquel y si el mismo acogió un culto provincial.

Con respecto a la primera cuestión, los restos del templo patriciense podrían bastar para responder afirmativamente. En cuanto al posible carácter

estatuto colonial mediante una deductio cesariana en 44-43 a. C. -completada por otra augústea c. 19 a. C.- (González, 2005: 406; Ventura, 2008: 99 y s.), ¿pudo instaurarse un culto a Divus Iulius en dicha ciudad?

39 Sobre los gobernadores y su papel en la difusión del culto imperial, $c f$. Haensch (1997: 381), Roddaz y Hurlet (2001: 162, 164) o Burrell (2004: 370 y ss.). Para el caso de Lusitania, Saquete (2005: 301 y ss.). En cuanto al debate entre la espontaneidad o la imposición del culto, recientemente Lozano (2010: 88 y ss.; 2011) ha defendido una "vía intermedia” que permitiría superar dicha dicotomía -historiográfica más que real- y entender mejor el surgimiento de aquel: la persuasión o inducción. 
provincial del edificio, debe tenerse en cuenta, primero, que hacia el 2 a. C. la Bética dedicó a Augusto en su Foro de Roma una estatua de oro de 100 libras de peso - probable representación de la provincia- en agradecimiento por su pacificación (CIL VI, 31.267). La inscripción que conmemora tan extraordinaria donación se integró en un conjunto de ofrendas realizadas al Princeps por gentes diversas ${ }^{40}$. Además de demostrar la existencia entonces de una cierta organización asamblearia en la Ulterior, el epígrafe evidencia la lealtad y gratitud que los béticos sentían hacia Augusto vivo (Caballos, 2011: 193 y ss.). ¿Cómo explicar que unos años más tarde observaran indiferentes cómo los de la Citerior manifestaban su devoción hacia aquel, ya divinizado, erigiéndole un magnífico templo en su capital?

Por otro lado, un proyecto constructivo de la magnitud del forum novum necesitó para su ejecución de mucho dinero. Aun cuando Tiberio hubiese colaborado en su financiación, como habría hecho con el templo de Tarraco (Domingo, 2015), si el recinto cordobés hubiese empezado a edificarse a principios de época tiberiana -c. 15-25 d. C.- es probable que, además de los patricienses, otros béticos ayudasen a cargar con sus gastos; incitados todos, quizá, por el gobernador provincial ${ }^{41}$ y con el ejemplo de los tarraconenses en mente. Ahora bien, que el templo de la c/ Morería se hubiese construido con fondos de cordobeses y otros provinciales no implicaría la existencia en Baetica, en época tiberiana temprana, de un culto provincial similar al desarrollado a partir de Vespasiano (Garriguet, 2002: 165 y ss.). Por su rango de caput provinciae y sede habitual del procónsul (Haensch, 1997: 178 y ss.), y debido a su atractivo para las élites béticas (Ventura, 2007a), Colonia Patricia pudo ser considerada por estas la ciudad idónea para erigir un colosal templo consagrado a la memoria de quien tantos beneficios otorgase a la provincia y a Córdoba

40 Vell., II, 39.2.

${ }^{41}$ El procónsul de la Bética pudo fomentar y controlar la ejecución del proyecto, pero probablemente habría quedado al margen de sus costes, pues estos solían recaer en las élites de las comunidades implicadas (Haensch, 1997: 381 y ss.; Roddaz y Hurlet, 2001: 156 y ss.). en vida ${ }^{42}$. Construido el edificio, no parece que el concilium prouinciae, si ya existía como tal, interviniese en el culto; de modo que su celebración quizá recayese durante décadas en sacerdotes locales. Ello explicaría la ausencia de flamines béticos hasta la regulación flavia del culto provincial -¿o surgieron antes; $c f$. Goffaux, 2013?-. Así, los casos de Córdoba y Tarragona mostrarían ciertas semejanzas (Le Roux, 1994: 402 y ss. $)^{43}$.

La devoción de Baetica hacia Divus Augustus pudo traducirse, pues, en la construcción de un gran recinto sacro en su capital y principal urbe entonces. Posteriormente, tal vez ese espacio fuese usado por el concilium y la administración provincial; pero sin que ello hubiese de generar conflictos con el antiguo foro de la colonia, al cual se adosó, ni con los órganos de gobierno de ésta, como sucedió en Carthago, capital de Africa Proconsularis (Gros, 1997). No obstante, el mayor escollo para aceptar la existencia de un templo provincial o supralocal en la Córdoba de época tiberiana temprana es el texto con el que se inicia este trabajo.

\subsubsection{Tercera posibilidad: época tiberiana tardía}

En efecto, las palabras de Tácito sobre la embajada de Hispania Ulterior que en 25 d. C. pidió permiso a Tiberio para dedicar un templo a este y a su madre han sido interpretadas por Étienne (1958: 416) o Fishwick (2004: 88 y ss.) como prueba de que en Baetica no existía entonces ningún templo provincial dedicado a Augusto. Fishwick (2002: 112) argumenta, además, que la construcción de dos posibles templos provinciales en fechas tan próximas habría supuesto un derroche para las arcas de los béticos. Pero no debe olvidarse que a principios

42 Corduba debió a Augusto, al menos, una segunda deductio colonial ( $c f$. n. 38) y, probablemente, la participación directa del Princeps en las obras el teatro (Ventura, 2007a: 97).

43 Para Ventura (2007b: 232, n. 23), la carencia de inscripciones de flamines de la Bética antes de época flavia se explicaría porque en época julioclaudia el flaminado provincial fue ejercido con carácter vitalicio por unos pocos individuos, cuya huella epigráfica sería hoy casi imposible de rastrear. 
de época julioclaudia la economía de las élites béticas era bastante holgada ${ }^{44}$, por lo que poseían medios suficientes para afrontar, si se les hubiera permitido, la edificación de dos templos provinciales con sólo unos años de diferencia.

No obstante, apoyándose en el texto de Tácito, así como en nuevos vestigios epigráficos y arqueológicos ${ }^{45}$ y en la revisión de otros antiguos, Ventura (2007b) ha formulado una propuesta sobre la funcionalidad y cronología del forum novum y su templo que ha sido aceptada por diversos investigadores (Peña, 2009: 575; Panzram, 2010: 389) ${ }^{46}$. Dejando al margen la hipotética restitución de la inscripción dedicatoria del templo, me centraré aquí en la posible vinculación del complejo cordobés desde sus inicios con el culto provincial y la administración de la Bética, así como en su supuesta construcción a partir del $25 \mathrm{~d}$. C.

Sobre lo primero, la argumentación expuesta más arriba podría considerarse igualmente válida ahora, pero bajo la premisa de que el adjetivo "provincial” no tendría la misma acepción que en época flavia, ni la que Ventura le otorga. Debería entenderse como un esfuerzo financiero de las aristocracias cordobesas y béticas para venerar conjuntamente a Augusto -y hacer ostentación de su riqueza con ánimo de promocionar- llevado a cabo en el lugar más idóneo para ello por su vitalidad económica e importancia político-administrativa: la capital de la

44 Por ejemplo, el cordobés Sexto Mario era quizá el hispano más rico de su tiempo, hasta el punto de suscitar la codicia de Tiberio; lo que a la postre le supuso la muerte (Tac., Ann., vi, 19; Dio. Cass., LVIII, 22, 2-3). Sobre la boyante situación económica de la Bética en época altoimperial -especialmente en época julioclaudia-, basada en la minería y el comercio del aceite, $c f$. Chic (2005, 2006).

45 Restos de peldaños de una escalinata, dos fragmentos arquitectónicos y otros tantos epigráficos - para insertar litterae aureae - de carácter monumental -además de una inscripción que documentaría un proceso judicial, aún inédita-, descubiertos en un muro medieval cerca del Guadalquivir (Ventura, 2007b: 217 y ss. y n. 3).

46 Pero no por Fishwick (2014b: 666), quien admite que el templo se dedicó a Divus Augustus, pero lo interpreta como "... an independent edifice (...) that was itself neither municipal nor provincial...”. Cf. además Portillo, op. cit. n. 28: 194 y ss.

(C) Universidad de Salamanca provincia. Qué papel desempeñó aquí el concilium prouinciae, si jugó alguno, no puede determinarse actualmente. En cuanto a si el forum novum fue el “centro provincial" de Baetica desde época tiberiana avanzada, constituyendo la sede del procónsul y su equipo (Ventura, 2007b: 232 y ss.), algunos de los argumentos esgrimidos merecen consideración ${ }^{47}$, pero otros generan dudas ${ }^{48}$. Y las inscripciones dedicadas a flamines o a emperadores que Ventura cita a favor de su hipótesis - por proceder de la c/ Morería y alrededores y mencionarse en ellas a la provincia- datan de momentos muy posteriores a los aquí tratados ${ }^{49}$; ello impide hoy día asegurar que desde época de Tiberio el forum novum funcionase como "Provincial Centre" 50 .

Por otro lado, cabe hacer dos objeciones a la cronología defendida por Ventura para la construcción de este complejo arquitectónico -a partir del 25 d. C.-. En primer lugar, tal datación choca con la asignada por Márquez (2002: 172) a la decoración arquitectónica del templo -c. 5-20 d. C.-; así como

47 En especial, la idea, sugerida también por Mateos (2006b: 346), de que el punto de llegada de los gobernadores provinciales a sus respectivos territorios se vinculase arquitectónica e iconográficamente con el espacio de Roma desde el que aquellos partían tras recibir sus destinos: el Forum Augustum (Dio. Cass., LV, 10, 2).

48 Si bien ha sido atribuida al forum novum (Peña et al., 2011: 67), no puede asegurarse que la exedra con schola recuperada en un vertedero bajoimperial extramuros se ubicase originalmente allí (Portillo, op. cit. n. 28: 73-77).

49 Los epígrafes imperiales oscilan entre los años 40 del s. III d. C. $\left(C I L \mathrm{II}^{2} / 7,255\right)$ y mediados del s. IV d. C. (CIL $\left.\mathrm{II}^{2} / 7,265\right)$; los dedicados a (o por) sacerdotes provinciales van de finales del s. II a las primeras décadas del in d. C. (CIL $\mathrm{II}^{2} / 7,221,291,293$ y 295). Algunas de esas inscripciones proceden de otras zonas de Córdoba $\left(C I L \mathrm{II}^{2} / 7,256\right.$ y 291) o carecen de localización segura $\left(C I L \mathrm{II}^{2} / 7,259\right)$.

50 Ventura equipara en funciones al forum novum con el recinto surgido junto al foro colonial de Mérida, donde Mateos (2007: 390) sitúa el pretorium o sede del concilium lusitano. Pero para Mateos (2006b: 340) el forum novum cordobés, junto con el espacio emeritense presidido por el templo de la c/ Holguín y el que acogió al templo de Augusto en Tarragona, habrían sido "conjuntos provinciales de culto imperial-temenos, plaza y templo- sin que conozcamos, hasta el momento, más edificios públicos en el área”; de ahí que "no estaríamos realmente ante foros provinciales". 
con la enorme afinidad que esta evidencia con la del Mars Ultor, hasta el punto de que ambas parecen haber sido ejecutadas por los mismos artistas. Una construcción del templo cordobés $c .30 \mathrm{~d}$. C. ${ }^{51}$ imposibilitaría prácticamente que en él hubiesen intervenido los maestros que trabajaron en Roma. En segundo término, que Baetica decidiese dedicar un templo a Divus Augustus una década después de que lo hiciera Hispania Citerior manifestaría la negligencia de sus élites y cierta dejadez por parte de los gobernadores provinciales a la hora de fomentar la adhesión de aquellas a la casa imperial y a su fundador $^{52}$. Pero que los béticos adoptasen tal decisión tras rechazar Tiberio un templo para él y su madre, y aconsejar el culto a su divino predecesor ${ }^{53}$, sólo podría calificarse de despropósito. Una torpeza posible, pero poco probable tratándose de unos provinciales tan ligados a Roma y agradecidos a Augusto $^{54}$. ¿Cómo interpretar entonces el pasaje de Tácito? ¿Cabría deducir del mismo que antes del 25 d. C. existía o se estaba construyendo en Baetica un templo "provincial" para Divus Augustus? El mutismo del historiador latino al respecto ha llevado a diversos investigadores a rechazar esta posibilidad. Quizá quepa una explicación distinta para su silencio y para el "extraño" comportamiento de los béticos"

51 Entre el regreso de la embajada bética desde Roma y el inicio de facto de las obras debió de transcurrir cierto tiempo, lo que nos aproximaría a ese año.

52 Algo bastante extraño si se tiene en cuenta que en Baetica se aplicó con fidelidad y celeridad, por iniciativa del procónsul Vibio Sereno, el senadoconsulto sobre los honores funerarios concedidos a Germánico, como demuestra la Tabula Siarensis (Eck, 2001; Roddaz y Hurlet, 2001: 161).

53 Es decir, como segunda opción tras el estrepitoso fracaso de la primera. Kornemann (1901: 124) ya sugirió que la respuesta de Tiberio habría llevado a los béticos a dedicar, poco después de 25 d. C., un templo a Augusto.

54 La prosperidad general de la Bética, la riqueza de su capital y los nexos que cordobeses y otros béticos mantenían con Roma y en general con Augusto c. 5 a. C. han sido expuestos por Ventura (2007a). Habida cuenta de esa estrecha relación entre el Princeps y los béticos, ¿sería posible que dos décadas después estos se olvidasen por completo de aquel y no lo honrasen como se merecía justo tras su divinización?

55 González Herrero (2009: 441; 2015: 72 y ss.) ha reflexionado también agudamente sobre la peculiar solicitud

\section{Tácito, Asia, Baetica y el templo de Córdoba}

Acerca de la primera cuestión debe tenerse presente que, tras relatar el episodio del templo que los hispanos decidieron dedicar a Augusto en $\mathrm{Ta}$ rraco e indicar que tal actitud dio ejemplo a todas las provincias, no habría tenido sentido que Tácito aludiese a todas las embajadas provinciales dirigidas al emperador con idéntico propósito. Para él habrían resultado más dignas de mención las situaciones que se apartasen del "modelo" tarraconen$\mathrm{se}^{56}$. Así ocurrió con la legación enviada por Baetica en 25 d. C., que no manifestaba su devoción a Divus Augustus, sino a Tiberio y a su madre, al igual que habían hecho en $23 \mathrm{~d}$. C. los representantes de Asia ${ }^{57}$. ¿Por qué los béticos imitaron a los asiáticos y no a los tarraconenses? Según Eck (2001: 568 y ss.), la Bética formuló su anómala petición a Tiberio en agradecimiento por el juicio y condena de un exgobernador, el procónsul Vibio Sereno, acusado de cometer abusos contra los provinciales durante su mandato; curiosamente, un conflicto similar motivó la solicitud de Asia dos años antes ${ }^{58}$. Que la iniciativa de los béticos obedeciese a una causa semejante a la que provocó el deseo de los asiáticos de erigir un templo a Tiberio y a su madre -junto al Senado- resulta convincente, e invita a pensar en la existencia de paralelismos más estrechos entre las élites de ambas provincias a principios del s. I d. C. En efecto, cuando envió su embajada a Roma la Bética probablemente sabría que Asia había solicitado poco antes su segundo templo provincial, pues ya contaba con el construido en Pérgamo hacía décadas para el culto de Augusto y Roma ${ }^{59}$. Por disponer de dicho edificio Pérgamo fue descartada a la hora de decidir en qué urbe se emplazaría el templo autorizado por

de estos a Tiberio, considerándola un indicio -indirecto- de que el culto provincial a Divus Augustus ya existía en Hispania Ulterior en $25 \mathrm{~d}$. C.

56 En la misma línea, aunque en relación a Lusitania, se expresa Saquete (2005: 304 y ss.).

57 Tac., Ann. Iv, 15.

58 Tac., Ann. III, 66-69.

59 Dio. Cass., LI, 20, 6-9. 
Tiberio. Después de tres años de deliberaciones, el Senado eligió a Esmirna ${ }^{60}$.

La imitación del ejemplo de Asia por la Ulterior pudo responder al objetivo apuntado por Eck -agradecer a Tiberio su intervención contra un mal gobernador-, pero también a otro de mayor repercusión para el culto imperial: conseguir el permiso del césar para levantar en alguna de sus ciudades más notables un segundo templo provincial, en el supuesto de que ya existiera el de Córdoba para Divus Augustus. ¿De qué mejor manera demostrarían los béticos su lealtad y devoción a la domus Augusta, además de su riqueza y afán de promoción social, que emulando a una provincia tan rica y con espléndidas urbes como Asia? Esta hipótesis explicaría el desconcertante desinterés de Baetica por el culto a Augusto en 25 d. C., y su no menos sorprendente intención de proclamar la divinidad en vida de Tiberio. Lo que Hispania Ulterior pidió no fue sólo un delubrum con el que expresar su gratitud a este, sino una alternativa revolucionaria a la vía fijada por el emperador para el desarrollo del culto provincial en Occidente al autorizar el templo de Tarraco. En ella el objeto de culto pasaba a ser el príncipe viviente, no Divus Augustus. Esto podía consentirse y justificarse en Oriente, donde existía una larga tradición de veneración a los gobernantes vivos (Price, 1984: 23 y ss.; Fishwick, 1987: 6 y ss.). Pero no en las provincias occidentales, pues ello habría hecho peligrar la estabilidad de Tiberio en el trono -rompiendo con la moderación de $\mathrm{Au}$ gusto en cuestión de honores divinos, especialmente a nivel provincial (Fishwick, 1987: 73 y ss., 83 y ss.; 2014a) - ${ }^{61}$ y la propia continuidad del régimen. Se entiende bien así el discurso, teñido de modestia, que el emperador pronunció ante los senadores en respuesta a la petición de los béticos; muy similar al recogido en la carta escrita años antes a

60 Tac., Ann. Iv, 55-56. Además de Pérgamo y Esmirna, entre la segunda mitad del s. i y el iII d. C. otras ciudades asiáticas albergarían también santuarios provinciales -a veces más de uno- administrados por su koinon; por lo cual recibieron el título honorífico de neokoros (Burrell, 2004).

61 Sobre este tema véase también el clásico, pero aún muy válido, trabajo de Charlesworth (1939). los habitantes de la ciudad de Gitio -en el Peloponeso-, quienes deseaban tributarle honores divinos (Paci, 2008: 195-197; Lozano, 2010: 86). El año $25 \mathrm{~d}$. C. Tiberio dejaba claro que el culto provincial en Occidente no podía seguir cauces distintos a los que había marcado a los tarraconenses; debía centrarse en el emperador divinizado. Por tanto, la Bética habría de conformarse con un único templo provincial, el que quizá se estaba construyendo ya en Córdoba para el culto a Divus Augustus. Pero esta situación tal vez no se mantuviese inalterable a lo largo del periodo julioclaudio; y menos aún cuando la nómina de emperadores divinizados comenzara a incrementarse...

\section{Conclusiones}

El descubrimiento en Córdoba del llamado forum novum y su colosal templo ha reavivado en los últimos años el debate, nunca cerrado, sobre el origen del culto provincial en Baetica. En efecto, la datación del complejo cordobés de la c/ Morería en las primeras décadas del s. I d. C. no sólo equipara a Colonia Patricia con las otras dos capitales provinciales hispanas, Tarraco y Augusta Emerita, que contaron asimismo entonces con recintos distintos a sus foros presididos por aedes monumentales dedicadas a Divus Augustus. También ha sembrado serias dudas sobre la supuesta implantación del culto provincial bético en época flavia, admitida tradicionalmente por los historiadores. ¿Pueden los restos descubiertos en Córdoba utilizarse como argumento para contradecir la opinión de aquellos, basada en un controvertido texto de Tácito y en la ausencia -hasta ahora- de flamines provinciales preflavios? Ello depende de dos factores: la cronología inicial del templo patriciense; y el significado que se otorgue al adjetivo provincial aplicado al Occidente romano y a la época julioclaudia.

Por lo que atañe al factor temporal, la información arqueológica actualmente disponible sitúa el inicio de las obras del forum novum y su templo en algún momento entre c. 5-30 d. C. Si tal hecho tuvo lugar con Augusto aún vivo, dicho espacio no pudo proyectarse para acoger el culto provincial, mientras 
que, por el contrario, una datación en época tiberiana haría muy probable o casi segura su relación con el mismo. Por otro lado, determinadas circunstancias históricas -el papel desempeñado por Colonia Patricia en el contexto de Batica a comienzos de la etapa imperial, las fortunas y ambiciones de muchos béticos, su gratitud al Princeps, su estrecha vinculación a Roma, etc.- permiten pensar que los hispanos de la Ulterior habrían emulado a los de la Citerior poco después de que estos recibieran permiso para erigir un templo a Augusto en Tarraco ¡y no una década más tarde y como solución de compromiso! Ello conduciría a fechar el comienzo de la construcción del complejo cordobés en época tiberiana temprana $-c .15-25$ d. C. $-\mathrm{y}$ a defender su dedicación, como en el caso tarraconense, a Divus Augustus.

En cuanto al factor semántico o conceptual, cada vez resulta más evidente que eso que denominamos culto provincial debería entenderse, para las zonas más romanizadas de Occidente como la Bética, como un fenómeno dinámico surgido justo tras la divinización de Augusto y que evolucionó a lo largo del s. I d. C.: desde un estado inicial de cierta indefinición con Tiberio hasta su consolidación como forma de veneración colectiva de una provincia hacia el poder imperial en tiempos de Claudio y, sobre todo, Nerón -cuando Roma tuvo un nuevo emperador divinizado, Divus Claudius-; y su posterior ordenación jurídica bajo los flavios, incluyendo explícitamente desde entonces como objeto de culto tanto a los divi como a los césares vivos.

¿Cómo se organizó y celebró el culto provincial en Batica en el periodo julioclaudio sin contar, aparentemente, con sacerdotes específicos? ¿Dónde tuvieron su sede entonces el concilium prouinciae y los órganos de gobierno de la Bética? ¿Dispuso esta en algún momento de más de un templo, como sucedió en Asia? Estas y otras preguntas sólo podrán responderse a partir de futuros hallazgos arqueológicos y epigráficos, y mediante nuevas reflexiones.

\section{Bibliografía}

Abaecherli, A. L. (1935): "The Institution of Imperial Cult in the Western Provinces of the Roman
Empire", Studi e Materiali di Storia delle Religioni, xI, pp. 153-186.

Alarcón, C. (2013): "La devotio ibérica y R. Étienne: ¿El origen del culto imperial en Hispania?”, Antigüedad, Religiones y Sociedades, 11, pp. 209-226.

ÁlvÁrez, J. M. ${ }^{a}$ y Nogales, T. (2003): Forum Coloniae Augustae Emeritae. "Templo de Diana”. Mérida.

Bullo, S. (2002): Provincia Africa. Le città e il territorio dalla caduta di Cartagine a Nerone. Roma.

Burrell, B. (2004): Neokoroi. Greek Cities and Roman Emperors. Leiden.

Caballos, A. (2011): "La Bética como referente indicador en la documentación epigráfica". En CABAllos, A. y Lefebvre, S. (coords.): Roma, generadora de identidades. Madrid, pp. 185-207.

Caballos, A. y Deininger, J. (1965): Die Provinziallandtage der römischen Kaiserzeit von Augustus bis zum Ende des 3. Jahrhunderts. München-Berlin.

Calandra, E. (2000): "Documenti inediti sul tempio di Roma e di Augusto a Ostia", Römische Mitteilungen, 107, pp. 417-450.

Castillo, C. (1998): "Los flamines provinciales de la Bética”, Revue d'Études Anciennes, 100, pp. 437-460.

Castillo, C. (1999): "Los flamines provinciales. El caso de la Bética”. En Rodríguez Neila, J. F. y NavaRro, F. J. (eds.): Élites y Promoción social en la Hispania romana. Pamplona, pp. 201-218.

Castillo, E. (2015): "Tácito y el templo de Tarraco. Nueva propuesta de interpretación". En López VILAR, J. (ed.): Tarraco Biennal. Actes del 2 Congrés Internacional d'Arqueologia i Món Antic (Tarragona, 2014). Tarragona, vol. 2, pp. 171-180.

Charlesworth, M. P. (1939): "The Refusal of Divine Honours. An Augustan Formula", Papers of the British School at Rome, 15, pp. 1-10.

Chaves, F.; Melchor, E.; Oria, M. y Gil, R. (1999): "El paisaje urbano en los ss. I a. C.-I d. C. y la emisión de moneda local: el caso de Gades". En GonzÁLEZ, J. (ed.): Ciudades privilegiadas en el Occidente romano. Sevilla, pp. 87-99.

Chaves, F.; Melchor, E.; Oria, M. y Gil, R. (2000): "Los monumentos en la moneda hispanorromana", Quaderni Ticinesi di Numismatica e Antichità Classiche, xxix, pp. 289-317.

Chic, G. (2005): "El comercio de la Bética altoimperial”, Habis, 36, pp. 313-332.

Chic, G. (2006): "Movimiento de personas y aceite bético”. En Demougin, A. (eds.): Migrare. La formation des élites dans l'Hispanie romaine. Bordeaux, pp. 273-299. 
Delgado, J. A. (1998): Élites y organización de la religión en las provincias romanas de la Bética y las Mauritanias: sacerdotes y sacerdocios. Oxford.

Delgado, J. A. (1999): "Flamines Provinciae Lusitaniae", Gerión, 17, pp. 433-461.

Delgado, J. A. (2011): "El flaminado local y provincial en Lusitania. Contribución a la historia política, social y religiosa de una provincia hispana". En CARDoso, J. L. y Almagro-Gorbea, M. (eds.): Lucius Cornelius Bocchus. Escritor Lusitano da Idade de Prata da Literatura Latina. Lisboa-Madrid, pp. 231-244.

Domingo, J. A. (2015): "El templo de Augusto en Tarraco, A. Caecina Severus y la estandarización de la arquitectura gigantesca”. En López ViLAR, J. (ed.): Tarraco Biennal. Actes del 2 Congrés Internacional d'Arqueologia i Món Antic (Tarragona, 2014). Tarragona, vol. 2, pp. 191-196.

Eck, W. (2001): "La mirada a Roma. Asuntos en torno a la muerte de Germánico y su repercusión en la Bética”. En Carmona romana (Carmona, 1999). Sevilla, pp. 559-570.

EDMONDSON, J. (2015): "The Roman emperor and the local communities of the Roman Empire". En Ferrary, J. L. y ScHeID, J. (eds.): Il princeps romano: autocrate o magistrato? Fattori giuridici e fattori sociali del potere imperiale da Augusto a Commodo. Pavia, pp. 701-729.

Étienne, R. (1958): Le culte impérial dans la Péninsule Ibérique d'Auguste a Dioclétien. Paris.

Fishwick, D. (1987): The imperial cult in the Latin West. Leiden, vols. I. 1 y I.2.

Fishwick, D. (2000): "A new Forum at Corduba", Latomus, 59, pp. 96-104.

Fishwick, D. (2002): The Imperial Cult in the Latin West. Leiden, vol. III.I.

Fisнwick, D. (2004): The Imperial Cult in the Latin West. Leiden, vol. III.3.

Fishwick, D. (2012): "Lex de flamonio Provinciae Narbonensis. A Flavian provincial law and the government of the Roman empire". En Capogrossi, L. y Tassi, E. (eds.): Vespasiano e l'impero dei Flavi. Roma, pp. 149-168.

Fishwick, D. (2014a): "Augustus and the cult of emperor", Studia Historica. Historia Antigua, 32, pp. 47-60.

Fishwick, D. (2014b): "The Temple on the New Forum of Corduba and the Provincial Centre of Hispania Ulterior", Latomus, 73 (3), pp. 661-666.

Fiske, G. C. (1900): "Notes on the Worship of the Roman Emperors in Spain", Harvard Studies in Classical Philology, 11, pp. 101-139.

García, R. y Carrasco, I. (2004): "Hallazgos en el número 5 de la calle Morería y nuevo espacio público de Colonia Patricia", Anales de Arqueología Cordobesa, 15, pp. 145-172.

Garriguet, J. A. (2002): El culto imperial en la Córdoba romana: una aproximación arqueológica. Córdoba.

Goffaux, B. (2013): “CIL II²/5, 316 (Igabrum) y la cronología de los primeros flamines provinciales de la Bética", Archivo Español de Arqueología, 86, pp. 261-278.

Goldbeck, V. (2015): Fora Augusta: Das Augustusforum und seine Rezeption im Westen des Imperium romanum. Regensburg.

GonZÁLEZ, J. (2005): “Colonización y municipalización cesariana en la Ulterior". En Melchor, E.; Mellado, J. y Rodríguez Neila, J. F. (eds.): Julio César y Corduba (Córdoba, 2003). Córdoba, pp. 397-412.

GonZÁlez, J. (2007): "El origen del culto imperial en la Bética según la documentación epigráfica”. En Nogales, T. y GonzÁlez, J. (eds.): Culto imperial: política y poder (Mérida, 2006). Roma, pp. 173-189.

González Herrero, M. (2009): "La organización sacerdotal del culto imperial". En Andreu, J.; CabreRO, J. e RoDÀ, I. (eds.): Hispaniae. Las provincias hispanas en el mundo romano. Tarragona, pp. 439-452.

González Herrero, M. (2015): La implantación del culto imperial de la provincia en Hispania. Oxford.

Gradel, I. (2002): Emperor Worship and Roman Religion. Oxford.

Gros, P. (1987): "Un programme augustéen: le centre monumental de la colonie d'Arles", Jahrbuch des Deustchen Archäologischen Instituts, 102, pp. 339-363.

Gros, P. (1990): "Théâtre et culte impérial en Gaule Narbonnaise et dans la Péninsule Ibérique". En TRILlMich, W. y Zanker, P. (eds.): Stadtbild und Ideologie (Madrid, 1987). München, pp. 381-390.

Gros, P. (1997): "Les bâtiments administratifs de la Carthage romaine. Problémes d'identification et de localisation", Römische Mitteilungen, 104, pp. 341-350.

Gros, P. (2000): "L'évolution des centres monumentaux des cités italiennes en fonction de l'implantation du culte imperial". En Les élites municipales de l'Italie péninsulaire de la mort de César à la mort de Domitien entre continuité et ruptura. Roma, pp. 307-326.

Gros, P. (2009): "Le rôle de l'architecture sacrée dans la définition et la hiérarchisation des espaces de la ville romaine imperiale". En Mateos, P.; Celestino, S.; Pizzo, A. y Tortosa, T. (eds.): Santuarios, oppida $y$ ciudades. Mérida, pp. 329-344.

GrüNer, A. (2005): "Die Altäre des L. Sestius Quirinalis bei Kap Finisterre. Zur geopolitischen Konstruktion des römischen Herrschaftsraums", Madrider Mitteilungen, 46, pp. 247-266. 
Gutiérrez, M. ${ }^{a}$ I. (2007): Los opera sectilia cordobeses. Córdoba.

Haensch, R. (1997): Capita provinciarum: Statthaltersitze und Provinzialverwaltung in der römischen Kaiserzeit. Mainz am Rhein.

HänleIn-Schäfer, H. (1985): Veneratio Augusti. Eine Studie zu den Tempeln des ersten römischen Kaisers. Roma.

Hauschild, T. (1991): "El templo romano de Evora”. En Templos Romanos de Hispania. Murcia, pp. $107-117$.

Koortbojian, M. (2013): The Divinization of Caesar and Augustus: Precedents, Consequences, Implications. Cambridge.

Kornemann, E. (1901): "Zur Geschichte der antiken Herrscherkulte”, Klio, 1, pp. 51-146.

Krascheninnikoff, M. (1894): "Über die Einführung des provinzialen Kaiserkultus in römischen Westen", Philologus, 53, pp. 147-189.

LEón, P. (1999): "Itinerario de monumentalización y cambio de imagen en Colonia Patricia (Córdoba)", Archivo Español de Arqueología, 72, pp. 39-56.

Le Roux, P. (1994): "L'évolution du culte impérial dans les provinces occidentales d'Auguste à Domitien”. En Les Années Domitien (Toulousse-Le-Mirail, 1992). Pallas, pp. 397-411.

Livadiotti, M. y Rocco, G. (2005): "Il tempio di Roma e Augusto”. En Di Vita, A. y Livadiotti, M. (eds.): I tre templi del lato nord-ovest del Foro Vecchio a Leptis Magna. Roma, pp. 165-264.

López, I. y Garriguet, J. A. (2000): "La decoración escultórica del foro colonial de Córdoba”. En León, P. y Nogales, T. (coords.): Actas III Reunión sobre Escultura romana en Hispania (Córdoba, 1997). Madrid, pp. 47-80.

Lozano, F. (2010): Un dios entre los hombres. La adoración a los emperadores romanos en Grecia. Barcelona.

Lozano, F. (2011): "The creation of Imperial gods: not only imposition versus spontaneity". En Iossif, P. P.; Chankowski, A. S. y Lorber, C. (eds.): More than Men, less than Gods: Studies on Royal Cult and Imperial Worship. Leuven, pp. 475-519.

Lozano, F. y Alvar, J. (2009): "El culto imperial y su proyección en Hispania”. En Andreu, J.; Cabrero, J. y RodÁ, I. (eds.): Hispaniae. Las provincias hispanas en el mundo romano. Tarragona, pp. 425-438.

Lyasse, E. (2007): "Germanicus, flamen Augustalis et la création de nouveaux flaminats à Rome”, Gerión, 25 (1), pp. 305-328.

Macías, J. M.; Menchón, J. J.; Muñoz, A. y Teixell, I. (2007): "Excavaciones en la catedral de Tarragona y su entorno: avances y retrocesos en la investigación sobre el Culto Imperial”. En Nogales, T. y GonzÁLEZ, J. (eds.): Culto imperial: politica y poder (Mérida, 2006). Roma, pp. 763-787.

Macías, J. M.; Muñoz, A.; Peña, A. y Teixell, I. (2014): "El templo de Augusto en Tarraco: últimas excavaciones y hallazgos”. En Álvarez, J. M.a; Nogales, T. y RodÀ, I. (eds.): Centro y Periferia en el Mundo Clásico. Actas XVIII CIAC (Mérida, 2013). Mérida, vol. II, pp. 1539-1543.

Mar, R.; Ruiz de Arbulo, J. y Vivó, D. (2013): “Los genios de los conventus iuridici y el lugar de reuniones del concilium provinciae Hispaniae citerioris. ¿Una 'curia' de uso provincial en Tarraco?”. En Soler, B.; Mateos, P.; Noguera, J. M. y Ruiz de Arbulo, J. (eds.): Las sedes de los ordines decurionum en Hispania. Mérida, pp. 25-42.

Mar, R.; Ruiz de Arbulo, J.; Vivó, D. y Beltrán-CABallero, J. A. (2012): Tarraco. Arquitectura y urbanismo de una capital provincial romana. Volumen 1. Tarragona.

Mar, R.; Ruiz de Arbulo, J.; Vivó, D.; Beltrán-CaBAllero, J. A. y Gris, F. (2015): Tarraco: arquitectura y urbanismo de una capital provincial romana. Volumen 2. Tarragona.

Márquez, C. (1998): La decoración arquitectónica de Colonia Patricia. Una aproximación a la arquitectura y urbanismo de la Córdoba romana. Córdoba.

Márquez, C. (2002): "Talleres imperiales en la provincia Bética: el caso de Colonia Patricia e Italica". En Reggiani, A. M. (ed.): Villa Adriana. Paesaggio antico e ambiente moderno. Milano, pp. 169-180.

Márquez, C. (2004): "Baeticae Templa”. En Ruiz de Arbulo, J. (ed.): Simulacra Romae (Tarragona, 2002). Tarragona, pp. 109-127.

Márquez, C. (2009): "Transformaciones en los foros de Colonia Patricia”. En Noguera, J. M. (ed.): Fora Hispaniae. Murcia, pp. 105-121.

Márquez, C. y Ventura, Á. (2005): “Corduba tras las guerras civiles”. En Melchor, E.; Mellado, J. y Rodríguez Neila, J. F. (eds.): Julio César y Corduba (Córdoba, 2003). Córdoba, pp. 429-466.

Mateos, P. (2006a): "El templo: la traslación de los modelos metropolitanos a la capital de la provincia lusitana". En Mateos, P. (ed.): El "Foro Provincial" de Augusta Emerita: un conjunto monumental de culto imperial. Madrid, pp. 251-276.

Mateos, P. (2006b): "El culto imperial en el llamado 'Foro Provincial' de Augusta Emerita". En Mateos, P. (ed.): El "Foro Provincial' de Augusta Emerita: 
un conjunto monumental de culto imperial. Madrid, pp. 315-354.

Mateos, P. (2007): "El conjunto provincial de culto imperial de Augusta Emerita". En Nogales, T. y GonZÁlez, J. (eds.): Culto imperial: política y poder (Mérida, 2006). Roma, pp. 369-393.

Mateos, P.; Peña, A.; Stylow, A. y Ventura, A. (2011): "Novedades arquitectónicas y epigráficas sobre el recinto de culto imperial provincial de la Lusitania”. En Nogales, T. y RodÀ, I. (eds.): Roma y las provincias: modelo y difusión. Roma, vol. II, pp. 645-652.

Nogales, T. (2000): "El relieve histórico de M. Agrippa, los relieves de Pan Caliente y el altar del foro emeritense", Espacio, Tiempo y Forma, Serie II, Historia Antigua, 13, pp. 391-423.

PACI, G. (2008): "Tiberio e il culto imperiale”. En GASPERINI, L. y PACI, G. (eds.): Nuove ricerche sul culto imperiale in Italia. Roma, pp. 193-218.

Pailler, J. M. (1989): "Domitien, la loi des narbonnais' et le culte impérial dans les provinces sénatoriales d'Occident", Revue Archéologique de Narbonnaise, 22, pp. 171-189.

Panzram, S. (2003): "Los flamines provinciae de la Baetica: autorrepresentación y culto imperial", Archivo Español de Arqueología, 76, pp. 121-130.

Panzram, S. (2010): "Zur Interaktion zwischen Rom und den Eliten im Westen des Imperium: Hispanien, Nordafrika und Gallien", Madrider Mitteilungen, 51, pp. 368-396.

Pensabene, P. (2004): "Roma e le capitali provinciali. Contributi per lo studio dell'architettura e della decorazione archittetonica in marmo nella Hispania romana”. En Ruiz de Arbulo, J. (ed.): Simulacra Romae (Tarragona, 2002). Tarragona, pp. 175-200.

Pensabene, P. y Mar, R. (2004): "Dos frisos marmóreos en la Acrópolis de Tarraco. El Templo de Augusto y el complejo provincial de culto imperial". En Ruiz de Arbulo, J. (ed.): Simulacra Romae (Tarragona, 2002). Tarragona, pp. 73-86.

Pensabene, P. y Mar, R. (2010): "Il tempio di Augusto a Tarraco. Gigantismo e marmo lunense nei luogui di culto imperiale in Hispania e Gallia", Archeologia Classica, 61 (11), pp. 243-308.

Peña, A. (2009): "La decoración arquitectónica". En Ayerbe, R.; Barrientos, T. y Palma, F. (eds.): El Foro de Augusta Emerita. Génesis y evolución de sus recintos monumentales. Mérida, pp. 525-582.

Peña, A.; Gorostidi, D.; Macías, J. M.; Muñoz, A.; RodÀ, I. y Teixell, I. (2015): "Más datos sobre el templo del Divus Augustus de Tarraco. A propósito de una nueva inscripción”. En López Vilar, J. (ed.): Tarraco Biennal. Actes del 2 Congrés Internacional d'Arqueologia i Món Antic (Tarragona, 2014). Tarragona, vol. 2, pp. 181-189.

Peña, A.; Ventura, Á. y Portillo, A. (2011): "El templo consagrado a Divo Augusto y su temenos (Forum Novum)". En Córdoba, reflejo de Roma. Córdoba, pp. 59-67.

Price, S. R. F. (1984): Rituals and Power. The Roman imperial cult in Asia Minor. Cambridge.

RodÀ, I. (2007): "Documentos e imágenes de culto imperial en la Tarraconense septentrional". En NogaLes, T. y GonzÁlez, J. (eds.): Culto imperial: política y poder (Mérida, 2006). Roma, pp. 739-762.

Roddaz, J.-M. y Hurlet, F. (2001): "Le gouverneur et l'image du pouvoir impérial. Recherches sur la diffusion de l'idéologie dynastique en Occident au $\mathrm{I}^{\text {er }}$ siècle ap. J.-C.”. En Evers, C. y Tsingarida, A. (coords.): Rome et ses provinces. Bruxelles, pp. 153-166.

Ruiz de Arbulo, J. (2007): "Bauliche Inszenierung und literarische Stilisierung: das 'Provinzialforum' von Tarraco”. En Panzram, S. (ed.): Städte im Wandel. Hamburg, pp. 149-212.

Ruiz de Arbulo, J. (2009): "El altar y el templo de Augusto en la colonia Tarraco: estado de la cuestión". En Noguera, J. M. (ed.): Fora Hispaniae. Murcia, pp. 155-189.

Ruiz de Arbulo, J. (2014): “Tarraco, capital de conventus y de la provincia Hispania citerior. Una aproximación a sus funciones y a su urbanismo público como modelo escenográfico en relación con las ciudades romanas valencianas". En Olcina, M. H. (ed.): Ciudades romanas valencianas. Alicante, pp. 31-53.

Saquete, J. C. (2005): "L. Fulcinius Trio, Tiberio y el gran templo de culto imperial de Augusta Emerita", Epigraphica, 67, pp. 279-308.

Saquete, J. C. (2011): "L. Fulcinius Trio, L. Cornelius Bocchus y el templo del Divus Augustus en Mérida", Habis, 42, pp. 163-172.

Saquete, J. C. y Álvarez, J. M.a (2007): "Culto imperial en Augusta Emerita: complejos monumentales y documentos epigráficos". En Nogales, T. y GonzÁLEZ, J. (eds.): Culto imperial: politica y poder (Mérida, 2006). Roma, pp. 395-414.

STYLOW, A. (2006): "La epigrafía y el culto imperial en Augusta Emerita: nuevos epígrafes del conjunto provincial de culto imperial". En Mateos, P. (ed.): $E l$ "Foro Provincial' de Augusta Emerita: un conjunto monumental de culto imperial. Madrid: CSIC, pp. 297-314. 
Ventura, A. (2007a): "Bauliche und literarische Inszenierung. Die Eliten des Colonia Patricia und das Jahr 5 v. Chr.". En Panzram, S. (ed.): Städte im Wandel. Hamburg, pp. 87-126.

Ventura, A. (2007b): "Reflexiones sobre la arquitectura y advocación del templo de la calle Morería en el forum adiectum de Colonia Patricia Corduba". En Nogales, T. y GonzÁlez, J. (eds.): Culto imperial: política y poder (Mérida, 2006). Roma, pp. 215-238.
Ventura, A. (2008): “Una lastra 'campana' en Córdoba: Assinius Pollio, el anguraculum y la deductio de Colonia Patricia”. En García-Bellido, M. P.; Mostalac, A. y JimÉnez, A. (eds.): Del Imperium de Pompeyo a la Auctoritas de Augusto. Madrid, pp. 85-105. Weinstock, S. (1971): Divus Julius. Oxford.

Zanker, P. (1992): Augusto y el poder de las imágenes. Madrid. 